\title{
TRANSFERÊNCIAS VOLUNTÁRIAS GERAM DESEQUILÍBRIO FEDERATIVO
}

Coluna publicada em 28.8.2012: <http://www.conjur.com.br/2012-ago-28/ contas-vista-transferencias-voluntarias-geram-desequilibrio-federativo $>$

O Brasil é uma Federação, e o respeito à autonomia dos entes que a compõem é fundamental para sustentação desse sistema. Entre os vários aspectos em que se desdobra a autonomia dos entes federados, a autonomia financeira ocupa papel de destaque.

Os entes federados, em especial os chamados "entes subnacionais" (estados, Distrito Federal e municípios), precisam dispor de recursos suficientes para fazer frente a suas despesas, e sem depender dos demais, particularmente da União. A verdadeira, efetiva e imprescindível autonomia financeira depende, pois, do binômio "suficiência" e "independência" dos recursos financeiros.

A equação que permite ajustar as receitas às despesas em cada ente federado é por demais complexa. Envolve uma multiplicidade de fatores que fazem do estudo do federalismo fiscal uma tarefa árdua e ao mesmo tempo instigante, pois inúmeros são os instrumentos e possibilidades na busca de uma fórmula ideal, que está e continuará em permanente construção, dado o dinamismo das relações econômicas e sociais.

No âmbito dos gastos, há que se adequar os serviços pelos quais cada ente federado ficará responsável com sua capacidade de prestá-los de forma eficiente. Questão difícil e que não será objeto de abordagem neste texto, mas seguramente o farei em outra oportunidade dada a relevância e interesse do tema.

No que tange às receitas, o mesmo problema se verifica. Muitas são as fontes de receita, várias são as possibilidades arrecadatórias de que dispõe o Estado para angariar recursos dos cidadãos e das empresas. Como ajustar a distribuição dessas fontes aos diversos entes federados, de modo a compor parte da estrutura que sustentará um sistema adequado de partilha de recursos? 
De início, distribuem-se as competências tributárias, atribuindo a cada ente federado uma gama de tributos que poderá instituir e cobrar. No Brasil, a título exemplificativo, vemos, no âmbito dos impostos, a atribuição à União dos impostos sobre o comércio exterior, IPI, IR, IOF etc.; os estados ficam com o ICMS, o ITCMD e o IPVA; e os municípios com o IPTU, ITBI e ISS.

Não é difícil constatar de plano a imprecisão financeira causada por essa partilha, dado o comportamento diferente que a arrecadação de cada tributo assume nos diversos entes federados, tornando inadequada a divisão de recursos feita exclusivamente dessa forma.

Outros métodos complementam essa fórmula, como é o caso da partilha de receitas tributárias, a exemplo dos fundos de participação (principalmente o FPE - Fundo de Participação dos Estados e Distrito Federal, e FPM - Fundo de Participação dos Municípios), por meio dos quais percentuais dos recursos do IR e do IPI, impostos federais, são transferidos de forma automática e obrigatória a estados, Distrito Federal e municípios, segundo critérios basicamente regionais, populacionais e de renda per capita. ${ }^{1}$

Mesmo assim, o sistema não se mostra suficientemente adequado à complexidade que as estruturas econômicas e sociais exigem para atender as necessidades públicas em uma federação com múltiplos atores.

Por essa razão, o Brasil, como muitos outros países, dispõe de um amplo e complexo sistema de transferências chamadas de "voluntárias". São recursos à disposição, principalmente, da União, e também, em menor proporção, dos estados e municípios, que podem ser entregues a outros entes federados, seguindo critérios de conveniência e oportunidade, vinculados a programas governamentais específicos. Completam uma estrutura de "federalismo cooperativo", claramente presente em nosso país, em que os diversos entes da federação em regime de cooperação para, juntos, compartilharem recursos e atribuiçōes no fornecimento de bens e serviços públicos, tais como se verifica no caso da saúde, educação e outras tantas áreas de atuação do Poder Público.

Trata-se de um sistema que, bem utilizado, é extremamente útil e necessário para a correta partilha de recursos entre os entes federados, pois permite o atendimento das necessidades públicas da forma mais eficiente, e com a necessária flexibilidade exigida pelas peculiaridades dos serviços públicos, dos prestadores e dos beneficiários, além das demais circunstâncias que circundam cada caso.

Para quem se interessar por mais detalhes sobre esses fundos, escrevi o Federalismo fiscal e fundos de participação. São Paulo: Juarez de Oliveira, 2001. 
As transferências voluntárias, no entanto, são instrumentos que exigem mais atenção dos legisladores a fim de que se dediquem a regulamentar essa poderosa ferramenta de nosso federalismo cooperativo, tornando-a mais impessoal e insuscetível de distorções em seu uso, como, muitas vezes, se tem observado.

A regulamentação das transferências voluntárias é, hoje, escassa e essencialmente formalista, como a que se vê no artigo 25 da Lei de Responsabilidade Fiscal. Não há diretrizes gerais que indiquem de forma mais clara quem deve ser contemplado e quais critérios devem ser observados.

Soma-se a isso a constatação de que os municípios, especialmente os menores, dispõem de ínfima arrecadação tributária própria e dependem fortemente das transferências obrigatórias, tornando o FPM sua principal fonte de receitas. Receitas estas que, somadas, são consumidas com as despesas correntes, cobrindo a folha de pagamentos e outras despesas de custeio.

Com isso, chega-se ao quadro hoje existente, em que esses municípios, que são a esmagadora maioria, dependem, para qualquer investimento ou despesa nova, das transferências voluntárias oriundas da União e do estado a que pertencem. Transferências estas que nem sempre são concedidas por critérios exclusivamente técnicos e cuja liberação de recursos é muito utilizada como instrumento de barganha política.

Atualmente, as transferências voluntárias, mais do que instrumentos de aperfeiçoamento do federalismo fiscal cooperativo, transformaram-se em armas de destruição da autonomia financeira e, consequentemente, do federalismo brasileiro, subordinando municípios e estados à vontade da União. Há uma distorção do processo democrático por meio do qual são eleitos os governantes, uma vez que os responsáveis pela gestão dos entes subnacionais se veem compelidos a aceitar as ofertas que lhe são feitas pelos demais entes federados, sob pena de não terem recursos para atenderem as necessidades de sua população. Muitos prefeitos, por consequência, têm de destinar recursos conforme o interesse da União, detentora dos recursos e do poder de entregá-los a quem lhe convier.

Um indesejável desequilíbrio em nossa Federação, em que a União consegue impor sua vontade aos estados e estes, por sua vez, aos municípios, deixando estes últimos, que estão mais próximos da população e sentindo mais de perto suas reais necessidades, à mercê de verdadeiras "benesses" oriundas do, no mais das vezes, longínquo planalto central.

Da forma como hoje se encontra, o sistema de transferências voluntárias transforma nossos prefeitos em verdadeiros "Indiana Jones" modernos: embora não vão à Índia ou ao Peru em busca de tesouros enterrados, são constantemente 
forçados a deixar a cidade que deveriam administrar para deslocar-se à Esplanada dos Ministérios brasiliense atrás das polpudas transferências voluntárias bem escondidas nos gabinetes dos burocratas. Sem o chicote e o glamour de um Harrison Ford, armados apenas de suas pastinhas, cumprem tarefa certamente bem menos emocionante e, no mais das vezes, muito mais difícil... 